\title{
IMPLEMENTASI MODEL PEMBELAJARAN TWO STAY TWO STRAY BERBASIS CTL UNTUK MENINGKATKAN HASIL BELAJAR SISWA KELAS IV SD NEGERI KARANGREJO 2 DEMPET, DEMAK.
}

\author{
Hartatik \\ SD N Karangrejo 2 Dempet-Demak
}

\begin{abstract}
ABSTRAK
SD Negeri Karangrejo 2 terletak di Kecamatan Dempet Kabupaten Demak sangat jauh dari pusat Kecamatan. SD Negeri Karangrejo 2 termasuk SD dalam kategori ranking 10 besar di Kecamatan Dempet. Oleh karena itu potensi peserta didik SDN Karangrejo 2 termasuk cukup baik. Potensi tersebut perlu ditumbuhkembangkan. Berdasarkan data nilai guru, rata-rata nilai peserta didik kelas IV masih rendah, yaitu 6,5. Berdasarkan kondisi awal, peneliti menerapkan Model Pembelajaran Two Stay Two Stray pada pelajaran Ilmu Pengetahuan Alam khususnya dalam materi pokok Rangka Manusia. Rumusan masalahnya, bagaimana meningkatkan hasil belajar peserta didik kelas IV SDN Karangrejo 2 dalam materi pokok Rangka Manusia? Tujuan penelitian ini adalah sebagai berikut: (1) Untuk meningkatkan hasil belajar peserta didik Kelas IV SDN Karangrejo 2 dalam mata pelajaran Ilmu Pengetahuan Alam khususnya pada materi pokok Rangka Manusia. (2) Untuk meningkatkan aktifitas belajar peserta didik kelas IV SDN Karangrejo 2 dalam mata pelajaran IPA khususnya pada materi pokok Rangka Manusia. Setelah PTK dilaksanakan, maka hasil penelitiannya adalah sebagai berikut: (1) Rata- rata hasil belajar peserata didik kelas IV SDN Karangrejo 2 dalam mata pelajaran IPA khususnya pada meteri pokok Rangka Manusia dapat ditingkatkan, yaitu 7,2. (2) Aktifitas belajar peserata didik setelah diterapkan model pembelajaran Two Stay Two Stray dapat meningkat, solid, dan terkoordinasi. Berdasarkan hasil dari penelitian ini, maka dapat disarankan sebagai berikut: (1) Perlu dilakukan PTK lanjutan untuk materi pokok yang lain pada pelajaran IPA. (2) Model pembelajaran Two Stay Two Stray dapat diterapkan untuk kelas-kelas yang lain di SDN Karangrejo 2 Kecamatan Dempet.
\end{abstract}

Kata kunci : Two Stay Two Stray, CTL, IPA.

\section{PENDAHULUAN}

Mata pelajaran Ilmu Pengetahuan Alam SD merupakan salah satu disiplin ilmu yang sangat penting dalam hal pembekalan untuk melanjutkan sekolah di tingkat yang lebih tinggi dan untuk diterapkan pada kehidupan sehari-hari di masyarakat. IPA juga merupakan salah satu mata pelajaran UASBN sejak tahun pelajaran 2007/2008. 
SD Negeri Karangrejo 2 adalah sebuah SD yang terletak di desa yang masyarakatnya belum sepenuhnya menyadari akan pentingnya pendidikan. Mereka sekolah hanya apa adanya, sekedar mengikuti arus. Minat belajar peserta didik juga sangat rendah. Selama ini banyak siswa penulis yang menganggap mata pelajaran IPA sebagai momok, bahkan dianggap sebagai mata pelajaran yang menakutkan, membosankan, dan menjemukan. Keadaan ini berdampak pada aktivitas siswa yang sangat memprihatinkan. Masalah nyata, jelas dan mendesak untuk diselesaikan adalah sebagai berikut.a). Ada 3 peserta didik kelas IV yang nilai Akhir Semester tidak tuntas. Kompetensi para peserta didik untuk mengerjakan soal akhir semester belum baik dan perlu ditingkatkan. b). Berdasarkan data nilai guru, rata-rata nilai peserta didik kelas IV untuk materi pokok Rangka Manusia masih rendah yaitu 6,5. Rata-rata ini masih bisa ditingkatkan agar menjadi lebih besar dari 6,5. c).Aktivitas belajar peserta didik kurang berkembang. Dalam belajar kelompok, masih ada beberapa kelompok yang pasif. Keberanian peserta didik untuk bertanya kepada guru dan yang berani maju ke depan kelas untuk mengerjakan tugas tak lebih dari 2 anak. Penyebab masalahnya sangat jelas, yaitu: a). tidak semua peserta didik yang masuk ke SD Negeri Karangrejo 2, memiliki minat di bidang IPA; b). guru belum memperoleh cara mengajar yang efektif untuk meningkatkan hasil belajar peserta didik dalam pelajaran IPA.

Dari uraian di atas dipandang perlu untuk mencari model pembelajaran yang tepat dan menarik, agar proses pembelajaran semakin efektif dan kompetensi dasar peserta didik dapat secepatnya tercapai. Secara kolaburatif, penulis memilih model pembelajaran Two Stay Two Stray berbasis CTL ( Contextual Teaching and Learning) untuk meningkatkan prestasi peserta didik kelas IV SD Negeri Karangrejo 2 pada materi pokok Rangka Manusia. Diharapkan dengan diterapkanya model pembelajaran Two Stay Two Stray (Dua Tinggal Dua Tamu) berbasis CTL ini, maka hasil belajar peserta didik dapat meningkat. Adapun permasalahan dalam penelitian ini adalah “ Bagaimana meningkatkan hasil belajar peserta didik kelas IV SD Negeri Karangrejo 2 dalam materi pokok Rangka Manusia?" Tujuan penelitian yang ingin dicapai adalah menigkatnya hasil dan aktifitas belajar peserta didik dalam mempelajari materi pokok rangka manusia dengan menggunakan model pembelajaran Two Stay Two Stray.

Penelitian tindakan kelas ini diharapkan memberikan manfaat bagi siswa, guru dan sekolah. Bagi siswa diharapkan hasil belajar dan aktifitas siswa dapat meningkat. Bagi guru 
diharapkan adanya inovasi model pembelajaran yang merupakan sumbangan pemikiran dan pengabdian guru dalam turut serta mencerdaskan kehidupan anak bangsa. Selain itu bermanfaat pula bagi SD Negeri Karangrejo 2 diantaranya diperoleh panduan inovasi model pembelajaran Two Stay Two Stray yang diharapkan dapat dipakai untuk kelas - kelas lainnya di SD Negeri Karangrejo 2, dapat mengurangi jumlah peserta didik yang nilainya tidak tuntas, dapat meningkatkan perolehan nilai pada Ujian Sekolah, dapat meningkatkan peringkat SD Negeri Karangrejo 2 ditingkat Kecamatan.

\section{KAJIAN PUSTAKA}

\section{KTSP dan Pendekatan Kontekstual}

Saat ini sedang aktif dilaksakan Kurikulum Tingkat Satuan Pendidikan (KTSP) sebagai kurikulum 2004 (KBK). KTSP ini juga berbasis pada kompetensi yang harus dicapai peserta didik. Puskur Balitbang Depdiknas (2002:1) mendefinisikan kompetensi sebagai pengetahuan, keterampilan, dan nilai-nilai dasar yang direfleksikan dalam berpikir dan bertindak. KTSP merupakan kurikulum yang dirancang dan dikembangkan berdasarkan seperangkat kompetensi tertentu yang harus dipelajari dan ditampilkan peserta didik. Kompetensi dasar yang harus dicapai peserta didik melalui indikator hasil belajarnya telah disusun oleh pemerintah pusat melalui Pusat Kurikulum Balitbang Depdiknas.

a. Menekankan pada ketercapaian kompetensi dasar oleh peserta didik.

b. Berorientasi pada hasil belajar (learning outcomes) dan keberagaman.

c. Mengaitkan materi pelajaran dengan kehidupan nyata.

d. Sumber belajar tak hanya dari guru, tetapi tetap harus edukatif.

e. Penilaian menekankan pada proses dan hasil belajar dalam upaya mencapai kompetensi yang diharapkan.

Agar kompetensi yang diharapkan dalam pelajaran Ilmu Pengetahuan Alam (IPA) dapat dicapai dan ditingkatkan, peserta didik harus merasakan bahwa IPA berguna bagi kehidupannya. Di lain pihak, IPA amat terkait dalam kehidupan sehari-hari. Di lingkungan sekitar peserta didik banyak dijumpai dari segala aspek kehidupan hampir semua berkaitan dengan IPA. Misal dalam perdagangan, pembangunan rumah, bahkan dalam membuat kalender, inipun tidak terlepas dari Ilmu Pengetahuan Alam. Dirjen Dikdasmen (2002:1) menulis bahwa Pembelajaran Ilmu Pengetahuan Alam yang mengaitkan bahan ajarnya dengan kehidupan sehari-hari peserta didik 
disebut sebagai pembelajaran IPA dengan pendekatan kontekstual. Hal ini sangat diperlukan agar para peserta didik termotivasi untuk belajar.

Peserta didik perlu dilatih secara dini untuk menghubungkan Ilmu Pengetahuan Alam dengan kehidupan sehari-hari dan tahu manfaat Ilmu Pengetahuan Alam dalam kehidupan bermasyarakat. Para peserta didik tak harus memperoleh wawasan manfaat Ilmu Pengetahuan Alam dari guru saja, melainkan dari sumber lain secara mandiri, seperti dari majalah, koran, $\mathrm{TV}$, atau internet.

Dalam sebuah jurnal, Uri Zoller (1991:593) menuliskan bahwa Science, Technology, Enviroment, and Society (STES) mempunyai hubungan dominasi yang setara. Ini berarti, pembelajaran dengan pendekatan kontekstual sudah menjadi issue internasional. Di sinilah Ilmu Pegetahuan Alam yang kontekstual perlu diterapkan agar bersesuaian dengan Environment/lingkungan dan Society/ masyarakat.

Keterlibatan peserta didik untuk turut belajar secara aktif melalui implementasi KTSP yang berbasis kontekstual ini merupakan salah satu indikator keefektifan belajar. Peserta didik tidak hanya menerima saja materi pengajaran yang diberikan guru, melainkan peserta didik juga berusaha menggali dan mengembangkan sendiri. Dengan demikian, hasil pengajaran tidak hanya menghasilkan peningkatan pengetahuan tetapi juga meningkatkan ketrampilan berpikir. Hal tersebut juga dikuatkan oleh Eggen dan Kauchak (1988:1) yang menulis bahwa " Effective learning occurs when students are actively involved in organizing and finding relationships in the information by themselves."

Lambas dkk (2004:16) dalam materi Pelatihan Terintegrasi menulis bahwa belajar aktif adalah belajar yang melibatkan keaktifan mental (intelektual emosional) walaupun dalam banyak hal diperlukan keaktifan fisik. Kadar keaktifan siswa antara teachercentered lawan Student-centered. Kadar keaktifan siswa atau kadar CBSA (Cara Belajar Siswa Aktif) menurut Mc Keachie ditentukan oleh tujuh dimensi atau factor sebagai berikut.

a. Partisipasi siswa dalam menetapkan tujuan kegiatan pembelajaran.

b. Tekanan pada upaya mencapai tujuan afektif dalam pembelajaran.

c. Partisipasi siswa dalam proses pembelajaran terutama dalam interaksi antar siswa.

d. Penerimaan guru terhadap perbuatan ataupun kontribusi siswa yang kurang relevan bahkan salah sama sekali. 
e. Kekohesifan kelas sebagai kelompok

f. Kesempatan yang diberikan kepada siswa untuk mengambil keputusa-keputusan

penting dalam kehidupan sekolah.

g. Jumlah waktu yang dipergunakan untuk menanggulangi masalah pribadi siswa baik yang berhubungan ataupun tidak berhubungan dengan mata pelajaran.

Tujuh dimensi di atas dapat diterapkan di dalam pengelolaan pembelajaran Ilmu Pengetahuan Alam dalam berbagai variasi metode dan model pembelajaran. Keaktifan siswa dalam mengikuti pembelajaran dapat pula ditingkatkan dengan memberikan motivasi. Motivasi adalah daya penggerak yang mendorong seseorang untuk melakukan sesuatu dengan tujuan tertentu. Motivasi terbaik adalah motivasi instrinsik. Suatu motivasi yang tumbuh dari kesadaran diri pribadi yang didorong oleh cita-cita ataupun harapan pribadi. Motivasi ekstrinsik adalah motivasi yang tumbuh karena pengaruh dari luar. Untuk memotivasi siswa pada awal pembelajaran dapat digunakan cerita menarik, masalah menantang, sejarah para ilmuwan, gambar menarik, atau yang lainnya.
Adapun beberapa cara yang dapat meningkatkan minat belajar siswa adalah:

a. mengaitkan topik yang dibahas dengan kegunaannya di masyarakat;

b. memberi kesempatan mendapatkan hasil yang baik (sense of succes);

c. menggunakan variasi metode/model dalam proses pembelajaran;

d. mengaitkan materi baru dengan materi lama.

Saat ini kita berada dalam era globalisasi, informasi, dan komunikasi yang terbuka. Peserta didik mulai mengenal dunia kemajuan tak hanya lewat guru tapi juga lewat pencarian secara mandiri. Kemajuan sains dan teknologi sangat transparan. Oleh karena itu, pemahaman melalui pembelajaran Ilmu Pengetahuan Alam tidak bisa dilepaskan dari komunikasinya terhadap teknologi dan manfaatnya bagi kehidupan bermasyarakat. Inilah esensi KTSP di era otonomi bidang pendidikan. Dalam jurnal yang dikeluarkan oleh Balitbang Dikbud, Budiono dan Ella Yulaewati (1999) menulis bahwa hidup di era informasi, diperlukan pemahaman, komunikasi, dan perhitungan. Pemahaman diterjemahkan sebagai kemampuan memahami makna dan implikasinya. Ini akan 
dicapai jika strategi yang diterapkan guru tepat dan mengacu pada penemuan dari peserta didik itu sendiri. Penemuan ini bisa diperoleh melalui proses pembelajaran yang menggunakan model Two Stay Two Stray.

Pentingnya kontekstual sebagai penunjang aktivitas yang signifikan dari peserta didik ini juga diungkapkan oleh Elaine B. Johson (2002:3) yang menulis bahwa "Contexstual teaching and learning engages students in significant activities that help them connect academic studies to their contextin real-life situations." Berkaitan uraian di atas, maka peserta didik kelas IV SDN Karangrejo 2 perlu dioptimalkan aktivitas belajarnya sehingga memiliki kompetensi yang diharapkan, sesuai dengan tuntutan KTSP.

Menurut Budiyono (2002:1) kompetensi merupakan pengetahuan, keterampilan, dan nilai-nilai dasar yang direfleksikan dalam kebiasaan berpikir dan bertindak. Kebiasaan berpikir dan bertindak secara konsisten dan terus menerus dapat memungkinkan seseorang untuk menjadi kompeten, dalam arti memiliki pengetahuan, ketrampilan, dan nilai-nilai dasar untuk melakukan sesuatu. Seharusnya dengan suatu tindakan kelas, pengetahuan, keterampilan, dan nilai-nilai dasar yang dimiliki peserta didik SDN Karangrejo 2 tentang Rangka Manusia dapat lebih ditingkatkan pula.

\section{Model Pembelajaran Two Stay Two Stray (Dua Tinggal Dua Tamu)}

Amin Suyitno (2009) menulis bahwa pembelajaran adalah upaya menciptakan iklim dan pelayanan terhadap kemampuan, potensi, minat, bakat, dan kebutuhan peserta didik yang beragam agar terjadi interaksi optimal antara guru dengan peserta didik serta peserta didik dengan peserta didik. Selanjutnya Trianto (2005:3) menulis bahwa model pembelajaran adalah tindakan pembelajaran yang dilakukan guru di dalam atau di luar kelas terhadap para peserta didiknya agar tujuan pembelajaran tercapai. Tetapi tidak semua tindakan pembelajaran dari guru terhadap peserta didiknya dapat disebut sebagai model pembelajaran. Tindakan pembelajaran guru baru dapat disebut sebagai model jika dipenuhi empat syarat sebagai berikut.

a) Ada penemunya.

b) Ada tujuan yang akan dicapai.

c) Ada tingkah laku yang spesifik.

d) Ada lingkungan yang perlu diciptakan.

Selanjutnya Spenser Kagan (1992) memaparkan bahwa Two Stay Two Stray adalah sebuah model pembelajaran yang kegiatan intinya meminta para siswa untuk memecahkan permasalahan, mencari alternatif jawaban dengan cara menggali informasi sebanyak-banyaknya dari 
teman sebaya atau dari kelompokkelompok lain. Untuk selanjutnya disimpulkan bersama anggota kelompoknya sendiri. Two Stay Two Stray sangat baik jika digunakan untuk melatih siswa dalam berinteraksi dengan lingkungan sehingga peserta didik dapat mendapatkan informasi seluas-luasnya sebagai alternatif jawaban. Langkah-langkah model pembelajaran Two Stay Two Stray adalah sebagai berikut.

a) Guru membentuk kelompok yang anggotanya

4-5 orang.

b) Guru mengemukakan konsep/permasalahan yang harus dipecahkan oleh setiap kelompok.

Contoh: 1. Sebutkan bagian-bagian dari rangka manusia!

2. Sebutkan fungsi dari rangka manusia!

3. Sebutkan 3 penyakit yang berkaitan dengan rangka manusia!

c) Tiap kelompok mengiventarisasi/mencat at alternatif jawaban bersama anggota kelompoknya.

d) Setelah selesai dua orang dari masing-masing menjadi tamu/mengunjungi kelompok yang lain. e) Dua orang yang tinggal dalam kelompok bertugas membagikan hasil kerja dan informasi kepada tamu mereka.

f) Tamu mohon diri dan kembali ke kelompok mereka sendiridan melaporkan temuan mereka dari kelompok lain.

g) Kelompok memecahkan dan membahas hasil kerja mereka.

h) Selanjutnya tiap kelompok melaporkan hasil diskusinya ke depan kelas.

i) Guru bersama siswa membuat kesimpulan atau guru melengkapi jawaban siswa sampai materi tuntas.

j) Guru memberikan tugas/PR secara individual kepada para peserta didik tentang materi pokok yang baru saja diajarkan/dipelajari. Model pembelajaran Two Stay Two Stray berbasis Contectual Teaching Learning (CTL) sangat mudah diterapkan di dalam kelas. Secara garis besar langkahnya meliputi: mengembangkan pemikiran bahwa belajar anak akan lebih bermakna jika dengan cara bekerja sendiri, mengkonstruksikan sendiri pengetahuan dan ketrampilan 
barunya, melaksanakan kegiatan inquiri, mengembangkan sifat ingin tahu dengan cara bertanya, menciptakan masyarakat belajar (kelompok belajar), menghadirkan model sebagai contoh pembelajaran, melakukan refleksi di akhir pertemuan, dan melakukan penilaian yang sebenarnya.

Berdasarkan pemasalahan dan kajian teoretik seperti telah diuraikan di atas, maka disusun kerangka berpikir PTK seperti uraian berikut. Peserta didik SD Negeri Karangrejo 2 Kecamatan Dempet Kabupaten Demak khususnya di kelas IV memiliki kemampuan cukup baik, tetapi jelas tidak semuanya memiliki kemampuan dan minat mempelajari IPA. Kenyataannya masih ada 3 siswa yang belum tuntas pada materi pokok Rangka Manusia. Kemapuan dan minat peserta didik dalam IPA harus dimulai dan dibangun dari kelas bawah. Jadi muncullah masalah mendesak untuk dipecahkan yaitu: (1). Bagaimana mempercepat pencapaian kompetensi dasar peserta didik kelas IV SD Negeri Karangrejo 2 Dempet di bidang pelajaran IPA materi rangka mausia? (2). Bagaimana meningkatkan hasil belajar dan aktifitas belajar peserta didik kelas IV SD Negeri Karangrejo 2 dalam pelajaran IPA khususnya pada materi pokok Rangka Manusia?.

Hasil belajar peserta didik kelas IV SD Negeri Karangrejo 2 di bidang pelajaran Ilmu Pengetahuan Alam masih memungkinkan untuk ditingkatkan. Karena itu secara kolaburatif peneliti dan para guru di SD Negeri Karangrejo 2 yang lain bersepakat untuk menerapkan model pembelajaran Two Stay Two Stray (Dua Tinggal Dua Tamu), untuk meningkatkan hasil belajar peserta didik dan aktifitas belajarnya, khususnya dalam materi pokok Rangka Manusia.

Berdasarkan tinjauan pustaka dan kerangka berpikir di atas, maka hipotesis tindakan penelitian ini adalah melalui penerapan model pembelajaran TwoStay Two Stray maka hasil belajar dan aktifitas belajar peserta didikkelas IV SD Negeri Karangrejo 2 dalam pelajaran Ilmu Pengetahuan Alam khususnya materi pokok Rangka Manusia dapat ditingkatkan.

\section{METODE PENELITIAN}

Subyek penelitian dalam penelitian ini adalah adalah peserta didik kelas IV SD Negeri Karangrejo 2, Kecamatan Dempet Kabupaten Demak tahun pelajaran 2013/2014. Mata pelajarannya adalah Ilmu Pengetahuan Alam pada materi pokok Rangka Manusia. Jumlah peserta didik kelas IV sebanyak 10 siswa. Banyaknya peserta didik putra ada 4 dan yang putri ada 6 siswa.

Lokasi penelitiannya di kelas IV SD Negeri Karangrejo 2, Desa Karangrejo, Rt 05/03 Kecamatan Dempet Kabupaten Demak. Waktu 
penelitian dimulai bulan Juli 2013 sampai Oktober 2013 pada semester I (ganjil). Sumber data berasal dari subyek penelitian, itu sendiri, yakni peserta didik kelas IV SD Negeri Karangrejo 2, melalui hasil pengamatan, hasil refleksi oleh tim peneliti, dan dari hasil tes. Jenis datanya adalah data kuantitatif yang berupa (a) penilaian kinerja kelompok, (b) pengamatan terhadap peningkatan aktifitas peserta didik, (c) hasil tes, dan (d) data hasil observasi/pengamatan terhadap efektiitas penerapan model pembelajaran Two Stay Two Stray (Dua Tinggal Dua Tamu).

Indikator keberhasilan dalam PTK ini adalah: a) Tercapainya tujuan ke I, yakni meningkatnya hasil belajar peserta didik kelas IV SD Negeri Karangrejo 2 dalam materi pokok Rangka Manusia, yang ditandai ratarata nilai hasil tes yang lebih dari 6,5. b) Tercapainya tujuan ke 2 yakni ada peningkatan aktifitas belajar peserta didik yang ditandai dengan:

a. Semua peserta didik ikut terlibat aktif dalam kegiatan di kelompoknya.

b. Banyaknya peserta didik yang berani bertanya lebih dari 2 orang.

c. Banyaknya peserta didik yang berani maju ke depan mengerjakan tugas/soal, lebih dari 4 orang, dan

d. Tidak ada peserta didik yang berbicara sendiri di luar konteks materi
pelajaran, pada saat
pelajaran berlangsung.

HASIL PENELITIAN DAN

PEMBAHASAN

\section{Hasil Pengamatan Siklus I}

Hasil pengamatan pada pelaksanaan pembelajaran pada Siklus I dirangkum sebagai berikut: 1) Guru mitra (sebagai pengamat) mengamati aktivitas kelompok peserta didik dan keberhasilan peserta didik dalam melaksanakan tugas. 2) Secara kolaboratif-partisipatif mengamati jalannya proses pembelajaran. 3) Ada 1 kelompok yang pasif saat memecahkan tugas/soal. Satu kelompok ternyata berbicara sendiri (gurau) di luar konteks pelajaran. 4) Peserta didik saat menyampaikan hasil pemikirannya, tampak antusias. Wakil dari kelompok 3 suaranya terlalu lemah sehingga tidak bisa didengar oleh semua peserta didik. 5) Pengamatan terhadap hasil latihan soal setelah peserta didik diberi tugas secara individual, ternyata ada 4 peserta didik yang belum mengerjakan tugasnya.6) Peserta yang aktif berani bertanya hanya ada dua. 7) Peserta didik yang berani mengerjakan tugas di papan tulis juga hanya ada dua. Guru sampai perlu memerintahkan kepada peserta didik yang lain untuk mengerjakan tugas. 8) Kelompok II salah dalam menyebutkan bagian rangka kepala, disebutkan diantaranya 
tulang bahu. 9).Kelompok I hanya dapat menjawab 1 soal, berarti ada 2 soal yang belum bisa dijawab dengan benar.

\section{Pengamatan Siklus II}

Hasil pengamatan pada pelaksanaan pembelajaran pada Siklus I dirangkum sebagai berikut: 1) Guru mitra (sebagai pengamat) mengamati aktivitas kelompok peserta didik dan keberhasilan peserta didik dalam melaksanakan tugas.2) Secara kolaboratif-partisipatif mengamati jalannya proses pembelajaran. 3) Ada 1 kelompok yang pasif saat memecahkan tugas/soal. Satu kelompok ternyata berbicara sendiri (gurau) di luar konteks pelajaran. 4) Peserta didik saat menyampaikan hasil pemikirannya, tampak antusias. Semua kelompok menyampaikan dengan baik, tidak ada lagi kelompok yang suaranya lemah. 5) Pengamatan terhadap hasil latihan soal setelah peserta didik diberi tugas secara individual, ternyata ada 1 peserta didik yang belum mengerjakan tugasnya. 6) Peserta yang aktif berani bertanya kepada guru sudah meningkat menjadi $40 \%$ dari jumlah peserta didik. 7) Peserta didik yang berani mengerjakan tugas di papan tulis juga sudah meningkat menjadi lebih dari 2 anak. 8) Kelompok III salah dalam menjawab tentang kegunaan rangka tengkorak. 9) Kelompok II hanya dapat menyebutkan 2 fungsi rangka.

\section{Pengamatan Siklus III}

Pada Siklus III, hasil pengamatan dirinci sebagai berikut: 1) Guru mitra (sebagai pengamat) mengamati aktivitas kelompok peserta didik dan keberhasilan peserta didik dalam melaksanakan tugas. 2) Secara kolaboratif-partisipatif mengamati jalannya proses pembelajaran. 3) Semua kelompok aktif saat memecahkan tugas/soal. Tidak ada yang berbicara sendiri (gurau) di luar konteks pelajaran. 4) Peserta didik saat menyampaikan hasil pemikirannya, tampak antusias. Semua kelompok menyampaikan dengan baik kepada seluruh peserta didik. 5) Pengamatan terhadap hasil latihan soal setelah peserta didik diberi tugas secara individual, ternyata semua peserta didik mengerjakan tugasnya dengan lengkap. 6) Semua peserta didik aktif dan berani bertanya kepada guru bila menemui kesulitan. 7) Semua peserta didik berani mengerjakan tugas di papan tulis. 8) Tidak ada kelompok yang salah dalam mengerjakan tugas. 9) Semua peserta didik mengerjakan test formatif dengan semangat dan rasa senang. 10) Nilai rata-rata test formatif adalah 7,2

Hasil pengukuran skor minimum, maksimum, rerata (mean), serta data persentase siswa yang sudah tuntas dan yang belum tuntas setiap siklus pembelajaran dirangkum dalam tabel berikut. 
Skor minimum, maksimum, rerata (mean), serta data persentase siswa yang sudah tuntas dan yang belum tuntas

\begin{tabular}{|c|c|c|c|c|}
\hline KATEGORI & $\begin{array}{c}\text { PRA } \\
\text { SIKLUS }\end{array}$ & $\begin{array}{c}\text { SIKLUS } \\
\text { I }\end{array}$ & $\begin{array}{c}\text { SIKLUS } \\
\text { II }\end{array}$ & $\begin{array}{c}\text { SIKLUS } \\
\text { III }\end{array}$ \\
\hline Min & 5,5 & 6 & 6 & 6,5 \\
\hline Max & 7 & 7 & 8 & 9 \\
\hline Mean & 6,5 & 6,5 & 6,8 & 7,2 \\
\hline Tuntas & $60 \%$ & $60 \%$ & $80 \%$ & $90 \%$ \\
\hline Belum Tuntas & $40 \%$ & $40 \%$ & $20 \%$ & $10 \%$ \\
\hline
\end{tabular}

\section{Pembahasan}

Hasil tes prasiklus menunjukan bahwa dari 10 siswa yang mendapatkan nilai diatas/sama dengan nilai Kriteria Ketuntasan Minimal ( 6,5 ) hanya 6 siswa sehingga ketuntasan belajar hanya mencapai $60 \%$ dengan nilai rata - rata 6,5 .

Pada Siklus I setelah dilakukan tindakan penelitian yaitu menggunakan Two Stay Tow Stray pada proses pembelajaran khususnya materi rangka manusia, diperoleh hasil ulangan harian dengan pencapaian nilai diatas KKM sebanyak 7 siswa, sedangkan siswa yang harus melaksanakan remidial sebanyak 3 siswa. Rata - rata nilai belum mengalami kenaikan/peningkatan. Pada siklus I peserta didik baru mengenal model Pembelajaran Two Stay Two Stray sehingga pelaksanaanya belum maksimal, ini nampak pada waktu pembentukan kelompok memakan waktu hingga 10 menit. Ada 2 kelompok yang pasif saat memecahkan soal/tugas, satu kelompok berbicara sendiri (gurau ) diluar konteks pelajaran. Ketika menyampaikan hasil pemikiran kelompok, ada satu kelompok yang suaranya terlalu lemah sehingga tidak bisa didengar oleh seluruh peserta didik, saat diberi tugas individual ada 4 peserta didik yang tidak mengerjakan tugasnya, peserta didik yang berani bertanya kepada guru saat menemui kesulitan hanya ada 2 anak dan yang berani maju kedepan kelas untuk mengerjakan tugas juga tak lebih dari 2 anak.

Pada Siklus II berdasarkan pengamatan dari 10 siswa yang mendapatkan nilai diatas nilai Kriteria Ketuntasan Minimal ( KKM ) ada 8 siswa sehingga ketuntasan belajar mencapai $80 \%$ dengan nilai rata - rata 6,8 . Siswa yang berani bertanya juga meningkat sebesar $40 \%$. Meskipun demikian masih ada 1 peserta didik yang belum selesai dalam mengerjakan tugas. Siswa yang 
berani maju mengerjakan tugas di papan tulis juga sudah lebih dari dua anak.

Pada siklus III setelah dilakukan perbaikan berdasarkan deskripsi pada hasil tindakan siklus II dapat dijelaskan sebagai berikut. Pada siklus III telah terjadi adaptasi terhadap perlakuan, baik metode maupun media yang digunakan, sehingga terdapat kenaikan rata - rata nilai maupun tingkat pemahaman terhadap materi pembelajaran. Berdasarkan rekapitulasi ketuntasan belajar pada siklus III dapat digambarkan sebagai berikut: Rata rata hasil tes adalah 7,2, sedangkan siswa yang tuntas sebanyak 9 siswa, sedangkan yang harus remidi ada 1 siswa, berarti mengalami peningkatan $10 \%$ dari $80 \%$ menjadi $90 \%$.

Perubahan tingkah laku juga sangat signifikan. Semua peserta didik aktif saat mengerjakan tugas/soal, tidak ada lagi yang bicara sendiri diluar konteks pelajaran, saat menmpilkan hasil pemikirannya tampak antusias, semua peserta didik mengerjakan tugas individu secara lengkap, semua aktif dan berani bertanya kepada guru saat menemui kesulitan, berani maju kedepan kelas untuk mengerjakan tugas, tidak ada kelompok yang salah dalam mengerjakan tugas/soal, semua peserta didik mengerjaka tes formatif dengan penuh semangat dan percaya diri.

Dari uraian di atas mulai dari Siklus I sampai dengan Siklus III nampak sekali perubahan yang terjadi pada peserta didik. Ini membuktikan bahwa model pembelajaran Two Stay Two Stray (Dua Tinggal Dua Tamu) berbasis CTL (Contextual Teaching and Learning) sangat tepat diterapkan untuk meningkatkan prestasi dan aktivitas belajar para peserta didik dalam mata pelajaran Ilmu Pengetahuan Alam khususnya pada materi pokok Rangka Manusia.

\section{SIMPULAN DAN SARAN \\ Simpulan}

Dari hasil pengamatan dan pembahasan dapat disimpulkan hal-hal sebagai berikut

1. Setelah diterapkan model pembelajaran Two Stay Two Stray pada mata pelajaran Ilmu Pengetahuan Alam khususnya materi pokok Rangka Manusia nilai rata-rata hasil belajar peserta didik meningkat dari 6,5 menjadi 7,2.

2. Dengan diterapkannya Model Pembelajaran Two Stay Two Stray, aktivitas belajar peserta didik juga meningkat.

\section{Saran}

Berdasarkan hasil dari penelitian ini, maka dapat disarankan sebagai berikut: (1) Perlu dilakukan PTK lanjutan untuk materi pokok yang lain pada pelajaran IPA. (2) Model pembelajaran Two Stay Two Stray dapat diterapkan untuk kelas-kelas yang lain di SDN Karangrejo 2 Kecamatan Dempet. 



\section{DAFTAR PUSTAKA}

Anderson, CA and Jennings, DL. 1980. When Experiences of Failure Promote Expectations of Succes : The Impact of Attributing Failure to Ineffective Strategies. Journal of Personality, 1 (48): 393 - 407.

Ansori M, Subagyo Bambag dan Masthoha. 2004. Ilmu Pegetahuan Alam kelas IV. Pemeritah Kabupaten Demak

Boediono dan Yulaewati, Ella. 1999. Penyusunan Kurikulum Berbasis Kemampuan Dasar. Jurnal Pendidikan dan Kebudayaan Balitbang Dikbud. 5 (19): 20 35 .

Boediono. 2002. Kurikulum Berbasis Kompeensi. Jakarta: Pusat Kurikulum, Balitbang - Depdiknas.

Dirjen Dikdasmen. 2002. Pendekatan Kontekstual (Contextual Teaching and Learning). Jakarta: Depdiknas.

Eggen and Kauchack. 1988. Strategiea for Teachers. Teachung Content and Tingking Skills. New Jersey: Prentice Hall.

Heckhause, H. 1974. How to Improve poor Motivation in Students. Paper presented at the 18-th International Conggres of Applied Psychology, Montreal, August.

Johnson, Elaine B. 2002. Contextual Teaching and Learning. California: Corwin Press, Inc.

Praselyono, dkk. 2005. Matematika Kelas IV. Demak: Pemerintah Kabupaten Demak.

Puskur Balitbang Depdiknas. 2002. Kurikulum Berbasis Kompetensi (KBK). Jakarta: Depdiknas.

Schwank, Inge. 1993. On the Analysis of Cognitive Structures in Agorithmic Thingking. The Jurnal of Mathematical Behavior. 12 (2). New Jersey. Abbex Publishing Corporation.

Schiefele dan Csikzentmihalyi. 1995. Motivation and Ability as Factors in Mathematics Experience and Achievement. Journal of Research in Mathematics Educations. 25 (2): 163-181.

Sugiharti, Endang. 2009. Tata Tulis Karya Ilmiah. Makalah di sajikan dalam Pelatihan IHT Modl - model Pembelajaran Inovatif dan Penulisan Karya Ilmiah. Semarang. 18 - 21 Januari.

Zoller, Uri. 1991. Teaching Learning Styles, performance, and student's Teaching Evaluation in S/T/E/S. Journal of Research in Science Teaching. 28 (7): 593-697. 